\title{
Dose-response problem in testing the ventricular hypothesis: II. Reply to Khavari, Heebink, and Traupman
}

ARYEH ROUTTENBERG, DEPARTMENT OF PSYCHOLOGY. NORTHWESTERN UNIVERSITY, Evanston, Ill. 60201

Khavari et al (1968) report that carbachol injected into the ventricle produces no appreciable increment in drinking and conclude (p.11) that "the hypothesis that ventricular modification may be responsible for carbachol-induced excessive drinking (Routtenberg, 1967) does not hold, a fact independently verified recently (Myers \& Cicero, 1968)." It was recently noted (Routtenberg, 1968) that the negative results of Myers \& Cicero (1968) may have been the result of the application of too much carbachol into the ventricle. The purpose of this note is to point out that the negative results of Khavari et al (1968) may be in part attributed to the same problem of application of excessive amounts of carbachol.

Although not called attention to by the authors, Khavari et al (1968) present data which tend to support the view (Fisher \& Levitt, 1967; Routtenberg, 1968) that the application of too much carbachol may mask drinking effects typically obtained at lower dosage levels. Thus, in Table 1 of Khavari et al (1968) are contained the water intake following application of five different dosage levels of carbachol. Interestingly, there is a clear relation between dose and response, but in the opposite direction. That is, the greater the dose employed the smaller the drinking response. The Spearman rank correlation coefficient was significant $\left(r_{8}=\right.$ $1.0, \mathrm{~N}=5, \mathrm{p}<.01$ ). Such results suggest that doses smaller than the smallest employed $(0.25 \mu \mathrm{g})$ should be used to test the adequacy of the ventricular hypothesis.
Two other factors may have contributed to the negative results. First, the authors report the effect of carbachol on $23 \mathrm{~h}$ water deprived animals. Such a procedure would raise baseline or control levels, and could mask any effects of carbachol-induced drinking that were present. Second, the vehicle employed was $10 \mu l$ of distilled water. Such a hypotonic solution when injected into the ventricle might act to suppress drinking behavior. Since these two procedural variables may have contributed to the lack of effect in the Khavari et al (1968) report, it would seem premature to conclude that these results do not support the ventricular hypothesis (Routtenberg, 1967). It is clear, however, that such findings will be of value in specifying the conditions under which the ventricle may mediate drinking behavior.

\section{REFERENCES}

FISHER, A. E., \& LEVITT, R. A. Drinking induced by carbachol: thirst circuit or ventricular modification? Science, 1967, 157, 839-841.

KHAVARI, K. A., HEEBINK, P., \& TRAUPMAN, J. Effects of intraventricular carbachol and eserine on drinking. Pyychon. Sci. 1968, 11, 93-94.

MYERS, R. D., \& CICERO, T. J. Are the cerebral ventricles involved in thirst produced by a cholinergic substance? Psychon. Sci., 1968, 10, 93-94.

ROUTTENBERG, A. Drinking induced by carbachol: thirst circuit or ventricular modification? Science, 1967, 157, 838-839.

ROUTTENBERG, A. Dose-response problem in testing the ventricular hypothesis: Reply to Myers and Cicero. Psychon. Sci., 1968, 11, 106. 